Отже, нині ми можемо спостерігати тенденцію «переоцінювання концепції педагогіки культури» [3]. У полі зору цієї концепції знаходяться не тільки конкретні теорії, що народилися на грунті педагогіки культури, але й ії досягнення, як джерело натхнень для роздумів над сучасними проблемами.

\title{
Література:
}

1. Gajda Janusz (red.), Pedagogika kultury. Historyczne osiągnięcia, współczesne kontrowersje wokół edukacji kulturalnej, perspektywy rozwoju, Wydawnictwo Uniwersytetu Marii Curie-Skłodowskiej, Lublin, 1998. S. 5.

2. Jurzysta Kazimierz. Pedagogika kultury w systemie współczesnej edukacji / Journal of Modern Science. Toм 4/35. 2017. S. 11-32.

3. Milerski B., Pedagogika kultury, [w:] Pedagogika, Z. Kwieciński, B. Śliwerski (red.), t. I, PWN, Warszawa, 2006. S. 223.

4. Pedagogika kultury a edukacja kulturalna. Rozwój historyczny, aktualność, perspektywy. Lublin-Dęblin, 1996. s. 395.

5. Śliwerski B. Współczesna myśl pedagogiczna. Znaczenia, klasyfikację, badania. Kraków: Oficyna Wydawnicza «Impuls», 2009. S. 42-44.

6. Suchodolski B. Uspołecznienie kultury. Warszawa, 1972. s. 199.

7. Wojnar I. Trwała obecność pedagogiki kultury, [w:] J. Gajda (red.) O nowy humanizm w edukacji, Kraków: Oficyna Wydawnicza «Implus»,1998. S. 16-25.

8. Wołoszyn S. Pedagogika kultury nie wymaga restytucji - jest żywa, [w:] J. Gajda (red.) Pedagogika kultury a edukacja kulturalna. Wydawnictwo UMCS-WSOSP, Lublin-Dęblin,1996. S. 12-15.

DOI https://doi.org/10.30525/978-9934-588-80-8-1.68

\section{ЗАСАДИ ГЕНДЕРНОГО ВИХОВАННЯ УЧНІВСТВА: ПОКАРАННЯ ТА ЗАОХОЧЕННЯ}

\author{
Шумська Д. І. \\ аспірантка кафедри педагогіки, \\ Криворізький державний педагогічний університет \\ м. Кривий Ріг, Дніпропетровська область, Україна
}

Європейська зорієнтованість розвитку України спонукає до значного оновлення вітчизняної системи освіти із урахуванням системи цінностей та принципів європейської спільноти. Ключовим у системі принципів існування демократичних держав $\epsilon$ принцип гендерної 
рівності, який має всеохоплюючий характер та стверджує рівність прав та можливостей як жінок так і чоловіків у всіх сферах життєдіяльності. Природно, цей принцип має увійти до засадничих основ вітчизняної системи освіти, на бути реалізованим на їі різних ланках.

Звертаємо увагу на учнівство, яке, на нашу думку, найбільш вразливо у визначеному аспекті. Учнівський вік - період, коли дитина поступово готується до входження у дорослий світ, набуває життєвих компетентностей, знань та навичок, що спрямують іiі подальший розвиток. Тож, на нашу думку, надзвичайно важливим $є$ впровадження гендерного підходу саме до ланки середньої освіти. На цьому етапі процес соціалізації учнів відбувається керовано, тому виключного значення набуває готовність вчителя до гендерного виховання учнівства.

Цей процес складний та, безумовно, супроводжується конфліктними ситуаціями, у розв'язанні яких також повинен брати участь вчитель. Проблема «шкільних конфліктів» представлена в науковому дискурсі працями педагогів та психологів, утім все ще залишається актуальною, оскільки саме у конфліктних випробовуваннях і формується особистість кожної людини. Т. Куниця, зокрема зазначає, що «конфлікти $\epsilon$ невід'ємною частиною життя кожної людини, але той вплив, який вони матимуть, залежить від того, якою мірою у підлітковому віці будуть сформовані навички ведення конструктивного діалогу та засвоєні шляхи виходу з конфліктних ситуацій» [1, с. 114.]

Виокремлюючи види конфліктів (за суб'єктами, формою прояву та наслідками) вчені пропонують низку способів/технологій регулювання конфліктів, звертаючи увагу на роль у цьому процесі класного керівника, вчителя-предметника, фахівців вузької професійної діяльності тощо. Утім, на нашу думку, у широкому та грунтовному вивченні сутності конфлікту, його причин, засобів запобігання та подолання, гендерний складник залишився на периферії наукового інтересу. Хоча саме тут вчитель повинен зважати на врівноваженість своїх суджень, оцінок дій учнів та учениць. Та поставити перед собою питання, чи не вплинула стать учнів/учениць на вибір вчителем стратегії розв'язання/запобігання конфлікту.

Певним формальним запобіжником у виникненні конфліктів, як форм девіантної поведінки учнів та учениць можемо вважати правила поведінки у школі. У цьому ракурсі звертаємося до наявній у сучасній освіті практики заохочення та стягнення, яка має достатньо чітко формалізовані прояви. Прикладом чого вважаємо «Правила заохочення та стягнення», які можемо віднайти на офіційних сайтах вітчизняних закладів загальної середньої освіти. Тож аналізу було піддано один 3 таких документів - «Правила заохочення та стягнення» тернопільської спеціалізованої школи I-III ступенів № 3 з поглибленим вивченням 256 
іноземних мов. Загалом цей документ справляє позитивне враження, оскільки у ньому йдеться і про демократизм в «організації навчальновихованого процесу», i про свідомий та відповідальний вибір учнівством життєвого шляху, і про «повагу до людської гідності», тощо [2]. Проте жодної згадки про рівність прав і можливостей і учнів, і учениць у документі не йдеться. Формально і стягнення, і заохочення стосуються лише учнів? Дівчата-учениці - відсутні у згаданому документі, вони прозорі, невизначені.

У документі докладно описані принципи накладання стягнення. Нашу увагу привернув перший пункт: «до відповідальності притягається тільки винний учень», утім, на нашу думку дівчатам легше уникнути покарання, оскільки в конфлікті учень/учениця переважно звинуватять хлопця. Оскільки гендерний стереотип: дівчата слабкі, потребують захисту, інколи спрацьовує у зворотному напрямі. Так само і конфлікти між дівчатами, що мають частіше витончений, прихований характер, відбуваються на рівні психологічної агресії, можуть бути непомітні вчителеві. Утім ці конфлікти $є$ дуже травматичними.

Освітня практика демонструє різні прояви гендерно забарвленої реакції вчителя на гарну чи погану поведінку i учениць, i учнів. Вивчення сучасної науково-методичної літератури із вказаного питання дозволяє виокремити ті аспекти, які, на нашу думку, повинен враховувати вчитель/вчителька в навчально-виховному процесі.

Передусім, це особливості звернення до учнівства. Вважаємо доцільним уникати статевого визначення учнів та учениць тоді, коли вчитель звертається до класу, чи хвалить чи докоряє учневі/учениці. Наприклад, не варто говорити: «Ти розумний хлопчик...», «Ти охайна дівчинка...», оскільки і хлопець, і дівчинка можуть бути і охайними, i розумними. Так само, коли вчитель робить зауваження, йому варто уникати конструкцій: «Як ти могла так вчинити, ти ж дівчинка...»/ «Як ти міг так вчинити, ти ж хлопчик...». Негарні дії і хлопців, і дівчат однаково потребують уваги вчителя, та його реакції. Проте вчинки, які дійсно, свідчать про прояви девіантної поведінки учнів та учениць не мають статевого визначення.

Із позицій гендерного підходу нагородження/покарання і хлопців, i дівчат повинні бути однаковим. Крім того, варто наголосити, про можливу підтримку і тих, і тих саме у гендерному аспекті. Варто відзначати спортивні та технічні перемоги дівчат та гуманітарні здобутки хлопців, при цьому не підкреслюючи, що це виключення 3 правил. Учні/учениці мають відчути свої перемоги не тому, що дівчинка стала (припустимо) гарною футболісткою, а тому, що вона особистість, яка досягла успіхів завдяки власним здібностям. Такий 
саме підхід має бути застосований і до учнів. Якщо він має гарний почерк, то це не «робить його дівчинкою», тому зауваження на кшталт: «Ти так гарно пишеш, як дівчинка...», «У нас дівчата так гарно не пишуть...» $є$ сумнівними, і скоріше образливими.

У якості висновків, вважаємо за необхідним наголосити, що від ступеня обізнаності вчителя щодо проблем гендерної педагогіки, його гендерної чутливості врешті залежить результат гендерного виховання, тобто гендерна культура учнів та учениць. Однакового заохочення i підтримки 3 боку вчителя потребують і дівчата, і хлопці. Правила учнівської поведінки у закладі освіти не мають «статевого визначення», порушення правил поведінки мають бути однакові і для хлопців, i для дівчат. Хоча питання, щодо необхідності існування цих «правил», вважаємо відкритим.

\section{Література:}

1. Куниця Т. Ю. Проблема конфліктів у шкільному колективі. Нові тендениії $і$ явища у дитячому $i$ молодіжному середовищі в Украйні: иивілізаційний, культурологічний, інформаційний виміри: збірник наукових праць за результатами методологічного семінару НАПН України ТОВ «Видавниче підприємство «Едельвейс», м. Київ, Україна, pp. 114-120. ISBN 978-966-2748-95-6

2. Правила заохочення та стягнення. Сайт тернопільської спеціалізованої школи I-III ступенів № 3 з поглибленим вивченням іноземних мов. https://school3.com.ua/uchniam/pravyla-zaokhochennia-ta-stiahnennia/ 